\title{
A Study of the Pottery of Madam Sọlá Sódàmọ́lá Abàtì of İjàyè, Abẹ́òkúta, Nigeria
}

\author{
Isaiah Túndé Ògúnjìmí* Nanashaitu A. Ùmórù-ọkkẹ́ Babásẹ̀hìndé A. Adémúlẹ̀yá \\ Department of Fine and Applied Arts, Ọbáfẹ́mi Awólọ́wọ University, PO box 2011, Ilé-Ifẹe, Nigeria
}

\begin{abstract}
Africans as at the beginning have arts, cultures, philosophies and beliefs system that guide their conduct and way of life. Art is a pivot in which all other aspects of life rotate and thus, it has been used as visual tool of changes through various media. Their arts have also been used as objects of regulation, control and orderliness in the society for the overall well-being of the people. All these visual elements communicate and unveil the invisible. One of those media is the art of pottery of the Yorùbá people of Southwestern Nigeria. This paper therefore examines the art of traditional Yorùbá pottery of Madam Sọlá Sódàmọ́lá Abàtì with a view to establishing the relationship between her art forms, contents and Yorùbá philosophy. The study also discusses the relevance and patronage of the art in its cultural environment in the contemporary times. The study engages both primary and secondary data. The primary data includes qualitative approach leaning on field investigation where oral interview was conducted with the potter. Direct observation method was also employed, and photographs were taken. Secondary data were derived from published and unpublished articles to complement the primary data. The study employs Art historical approach using descriptive and contextual methods of data analysis. Findings reveal that younger people are no more interested in the profession which is a pointer to extinction in the nearest future, however the continuous practice of the art is possible because of the patronage it enjoys in the contemporary times. The study also discovers that in spite of the treats occasioned by the importation of plastic and metal containers into our local markets, traditional pottery is still on going because of its primary use in the society. The study therefore concludes that the socio-cultural and household relevance of traditional Yorùbá pottery cannot be likened to foreign products. The study thus encourages the continuous practice and preservation of the distinctive tradition for the promotion of Yorùbá artistic and cultural patrimonies.
\end{abstract}

Keywords: Arts, Philosophy, Personage, Traditional Yorùbá Pottery, Socio-cultural Relevance

DOI: $10.7176 / \mathrm{ADS} / 84-01$

Publication date:August $31^{\text {st }} 2020$

\section{Introduction}

The Art of pottery in Nigeria is one of the most widely practiced although, the history of its origin is still largely indiscernible and that the little is known about the true history of the traditional industry (Okunna, 2004). Various assertions as to where pottery originated in Nigeria were given but the fact still remains that pottery is as old as man. Pottery is found in archaeological finds in various sites in Nigeria especially in Igbo-Ukwu, Nok and Ife (Shaw 1978, Igwillo 1983, Cillion 1984, Ojo 1986, Ahuwan 2003). Similarly, the Vanguard Media Limited (2011) claims that the earliest examples of pottery making in Nigeria were found in rock shelter of Dutsen Kongba near Jos, Kaduna, Afrikpo in Ebonyi State and in İwó Elệrù in the present-day Ondo State. Fowowe (1984) asserts that pottery seems never to have been recognised as art but, rather as craft especially in the west due to the classification which artifacts have been subjected to by Western theorists. The concern however is not about the type or classification of art that pottery belongs but, its relevance and significance in the society. Art generally in Africa has become part and parcel of the indigenous people.

Pottery is one of the oldest arts in Nigeria and, it is still in practice today because of the abundance and availability of its essential material and the various uses it performs in household and beyond. Aremu (2002) notes that pottery making is one of the most common industries of the Yorùbá, not only because of the raw material (clay) which is often readily available but also because this industry's products (vessels) are indispensable domestic needs of the people. Hence, the use and relevance of pottery to Yorùbá culture cannot be over stressed. This actually shows the relevance of traditional pottery to the African cultures generally. Pottery according to Vanguard Media Limited, (2011) is the act of making earth ware containers, the art of forming objects of clay in a moist plastic condition and then drying them by either exposure to sun and air, fire, baked in kilns or ovens.

Ùmórù-ọ̀kẹ (2016) defines Traditional pottery as the combination of pots, dishes, and receptacles that are hand-built with clay and fired in a clamp or open fire to make them functional, durable and permanent. In this connection, traditional pottery emphasizes three main factors: material, process and product that are responsible for the uniqueness of pottery profession. Traditional pottery is mainly practiced by the womenfolk and it is usually passed from mothers to their children and from one generation to the other. As a matter of fact, the whole process of traditional pottery making from the digging of clay to firing is inexpensive. Fowowe (1984) opines that Yorùbá as a people have a living tradition and this tradition finds expression in the symbolic art which they 
produce.

\section{Brief Historical Background of Abẹò̀úta}

Abẹòkúta being the capital of the present Ogun State in Nigeria is said to be the first independent State and one of the ancient towns of Yorùbá land under the kingship of Sódẹkẹ ${ }^{1}$ The so called Ėgbá, the subgroup of Yorùbá ethnic group is located about 81 kilometers southwest of Ibadan and 105 kilometers north of Lagos (Ùmórù-Ọ̀kẹ, 2011). The people are predominantly Christians, Muslims and traditionalists, and consequently, they value their traditions. This reveals their choice of vocations such as pottery, tie-dye, and wood carving among others ${ }^{2}$. These arts are practiced on a large scale in anticipation of foreign investment opportunities they enjoy with their proximity to Lagos State.

The famous Olúmọ Rock that brings about tourist attraction also popularises Abẹókúta to the outside country. According to Jegede Lanre, an informant, Ėgbá people settled around Olúmọ Rock for safety during the war between 1825 and 1830 on the directives of the Ifá Oracle led by chief Sódẹkẹ and; till today the people remain there. This indeed brought about the name, Abẹòkúta "Refuge among Rocks". Inside Watch Africa (2012) posits that Olúmọ Rock became the greatest strength and pillar of the Ėgbá people, as it puts them at a vantage position to sight their enemies from several kilometers away and allow them to properly strategise and make rise of the rock and the caves as protective shields against their enemies.

However, İjàyè the study area of which madam Solá Sódàmọ́lá Abàtì resides is a notable pottery centre in Abẹòkúta. İjàyè people of Abẹèkúta left their original location at Orile-İjàyè as a result of war and they were said to be the descendants of Aare Kúnrumí ${ }^{3}$ and his war chiefs Kukudi and Obilinti, (Ùmórù-Ọke 2011). The İjàyè people are deep rooted in the culture of Ėgbá people. These people were said to be the dominant pottery makers in İjàyè of Abẹòkúta till today. The İjàyè potters are mainly women who practice the tradition and they make various types of domestic utensils, religious and other functional pots revealing the essence of African people especially, the Yorùbá of Ėgbá land.

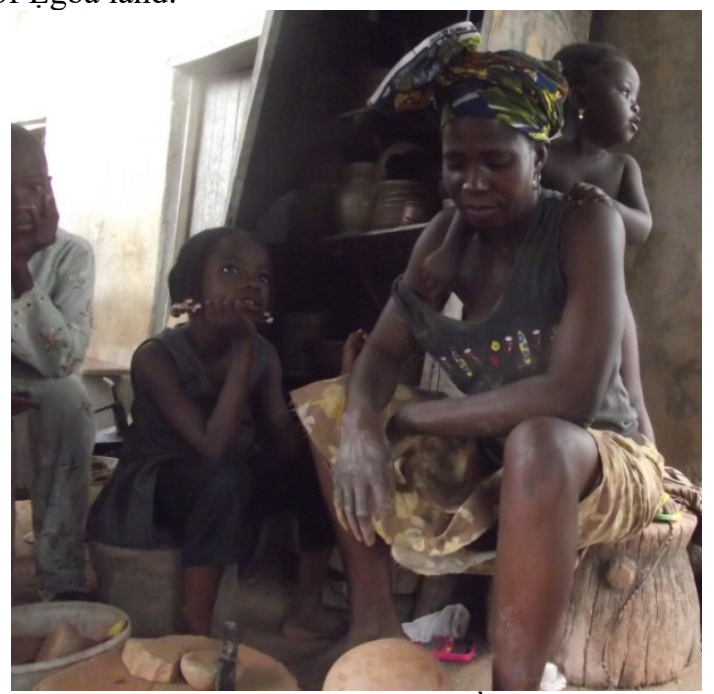

Plate 1: Madam Sọlá Sódàmọ́lá Abàtì, Ijàyè, Abẹokúta

Photographed by Clement Adésànyà, July, 2013.

\section{Biography and Professional Background of Solá Sódàmọ́lá Abàtì}

Madam Sọlá Sódàmọ́lá Abàti ${ }^{4}$, a traditional Yorùbá potter who resides in İjàyè Kúnrumí, Abẹòkúta in Ogun State, Nigeria was born into the family of Oyèbándé in Tánkẹ, Abẹòkúta about four decades ago as at the time of interview with her. She was married into the family of Sódàmọ́lá Abàtì in Abẹòkúta. Both her father's and husband's houses have nothing to do with her profession since the two families do not engage in any form of art or craft. According to her, she started the art of pottery through observation method of learning when she was about fifteen years of age. She did not learn it as a form of training under apprenticeship neither did she train in

\footnotetext{
${ }^{1}$ Sódẹkẹ́ was a hunter and leader of the Ẹgbá refugees who fled from the disintegrating Oyo Empire. He founded Egba town, Abẹ́òkúta in 1830. Sódẹkẹ was the first leader in Ėgbá land.

2 Jegede Lanre is an attendant in the court of Alake of Ẹgbá land, Abẹòkúta, Ògùn State: Personal Communication: June, 2013 at the Alake of Egbá Palace, Abẹòkúta, Ògùn State.

${ }^{3}$ Kúnrumí was a chief warrior after Ààrẹ Ọnàkakanfò in Orílẹ İjàyè of Old Oyo Empire now in Oyo State. His declaration of war with Alaafin of Oyo made some residents hurriedly moved out of İjàyè and resettled in the current Abẹ́òkúta.

${ }^{4}$ Sola Sódàmọ́lá Abàtì is a traditional Yorùbá potter residing in İjàyè Kúnrumí, Abẹòkúta, Ogun State: Personal Communication: June, 2013 in her workshop at İjàyè Kúnrumí, Abẹeòkúta, Ogun State.
} 
any formal school setting as a potter. She used to observe potters around her sometimes while working in their workshops. Her commitment to observing these potters motivated one of them who happened to be Mrs. Monsurat Àyándìran. Mrs. Monsurat took interest in this, young Sola. It was from Mrs. Monsurat that she learnt the traditional methods of pottery. Having learnt this method, it greatly influenced her art of pottery in which she becomes master today. She is mainly engaged in traditional hand-built method of pottery.

Madam Solá who is already gifted in the art of pottery sought more knowledge to complement the traditional method she is already used to by learning contemporary forms and techniques from Mr. İbíkúnlé who is currently the director of Atamora Pottery Center in Wáàsinmi, Ọșun State. She is so delighted in the art of pottery making as she earns her living through it. İjàyè which is the current location where she practices her pottery either by choice or through marriage has placed her in high regard. This has also influenced her professional works as a potter. It is claimed that the women of İjàyè are famous potters in Abẹòuúta as the people generally are reportedly creatively inclined (Ùmórù-Ọkẹ 2011). Irrespective of treats posed by the current civilization on our local product, Madam Sọlá wants her children to take after her in the art of pottery. The beauty of it is that she makes use of locally improvised tools such as timù (potsherd), combs, sea shells, corn comb and spatula of various sizes and, not sophisticated machine (Plates $2 a-2 d)$.

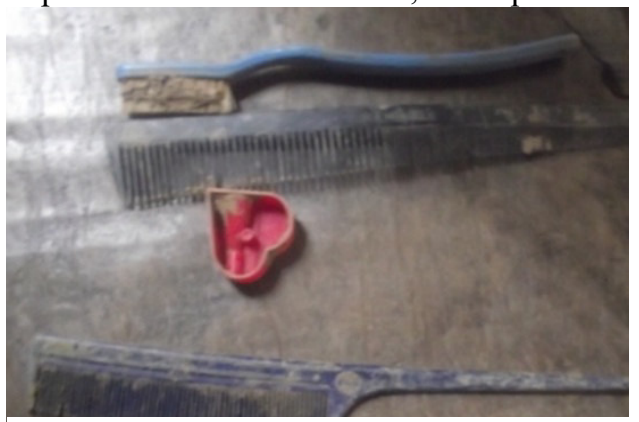

Plate 2a: Comb, Brush and Sharpener Photographed by Clement Adésànyà, 2013.

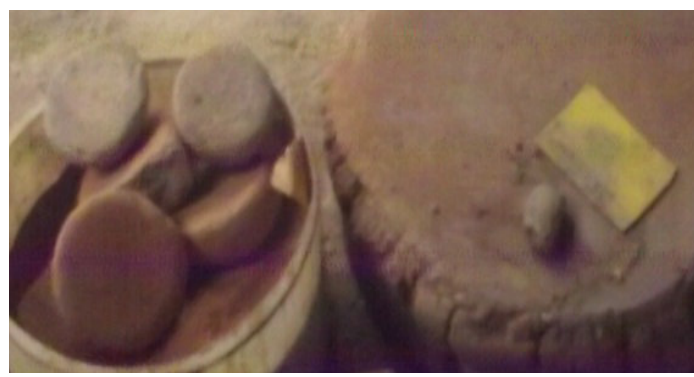

Plate 2c: Stones and plastic spatula, Photographed by Clement Adesanya, 2013.

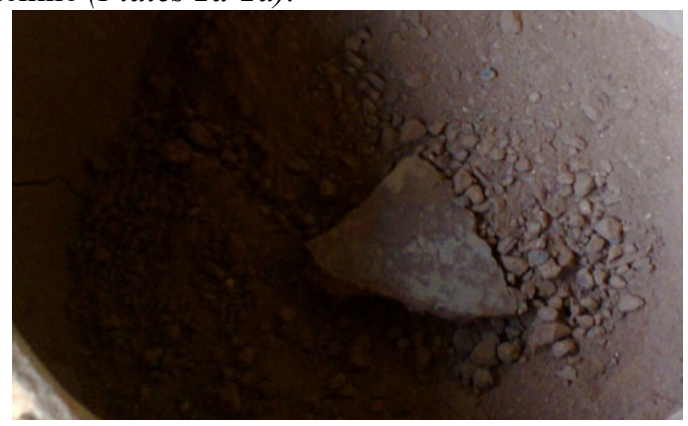

Plate 2b: Potsherd,

Photographed by Clement Adésànyà, 2013.

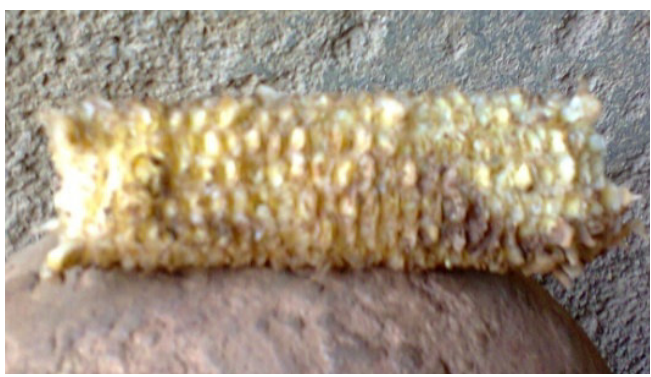

Plate 2d: Corn Comb used to make different textures on the pots while they are still wet Photographed by Clement Adésànyà, 2013.

The pottery products of Madam Sọlá are produced for all categories of people as those works serve both sacred and utilitarian purposes depending on the caliber of people who patronise them. She however claimed that, she makes her pottery vessels as ordinary art but the buyers may want to turn them to what they want and there is no ritual involvement in the process of making her pottery. She produces different forms and shapes, sells and gets paid so as to earn living.

\section{Sourcing and Preparation of Clay as The Only Material}

Clay is very much available to all everywhere as the core material for pottery. It is found at water side, dug and carried home. Clay needs to pass through purification before the process of pottery making starts. This is because raw clay contains a lot of impurities such as sand, rocks and other materials which need to be removed. After purification, the pure clay is mixed with water to make it malleable and then, kneaded to remove all air-bubbles. Madam Sọlá gets her raw clay from underneath the earth very close to where she resides in İjàyè. Clay is obtained and carried home for further process. The clay is pounded, soaked for about three days and sieved after which it is kneaded for proper pliability. Good clay is plastic and moldable after thorough kneading. It can also be folded, squeezed and pressed to form any aesthetic vessel. 


\subsection{Techniques and Processes}

The technique used by Madam Sọlá Sódàmọ́lá is not much different to the ones used in pottery centers all over Yorùbá land. The most populous techniques adopted by most Yorùbá potters are pinching and coiling. According to Ùmórù-Ộkẹ, (2011), these methods are as old as pottery itself. The methods existed prior to the introduction of potter's wheel. The techniques according to Madam Solá are peculiar to the types of pot and tools available. Hand built techniques incorporate coiling and pinching methods. The potters knead a lump of clay well fermented to a workable size and starts building. The pinching method is mostly used for small size vessels, while the coiling is suitable for the larger size vessels. In coiling method, a heap of clay is rolled and added to the top until a desired shape is formed.

The technique adopted by Madam Sọla is basically the combination of pinching and coiling depending on the form and size to be produced. However, the tools available determine the type of decoration that would be incorporated into the vessels. These tools include finger, beater, bean pods, comb, shells, corn comb (sùkù àgbàdo) and various sizes of spatula, (plates $2 a-2 d$ above). Those tools are used to impress patterns and apply element before the clay dries hard. Madam Sọlá also claims that "èepo irà" i.e. irà tree back is also soaked in water for like two days and the water is being infused with broom on the pots so as to make it shinning as a form of decoration after the firing. Sometimes, "tìmù" i.e. potsherd or stone is also used as tool to smoothen and burnish the pot vessels after firing. (Plate 3)

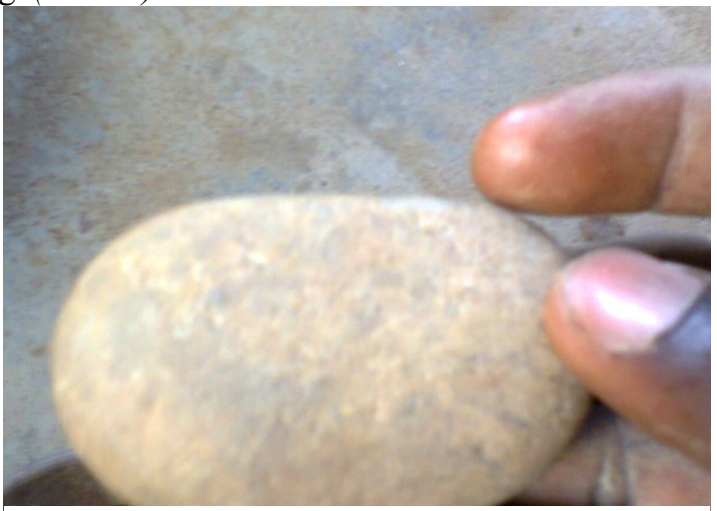

Plate 3: Stone,

Photographed by Iyìola Sóẹ́tán, 2013.

Firing is the process in which pottery vessels are transformed into more durable state through burning. The vessels cannot be used without firing, especially for cooking and other household uses. The open firing is used by Madam Sọlá and before the actual firing, pre-heating which allows the remaining water in the pottery vessel to dry off is done. This is done in order to prevent cracking during the actual firing. Fired vessels are well functional and preserved unlike the unfired ones. Sometimes pottery vessels are baked in hole in the ground and, in other cases as with Madam Solá; they are fired in the open space with wood, grass and leaves. (Plate 4). The maximum temperature attainable by such firing is $700^{\circ} \mathrm{C}\left(1200^{\circ} \mathrm{F}\right)$. At this stage, chemical changes take place that turn clay into durable and permanent state.

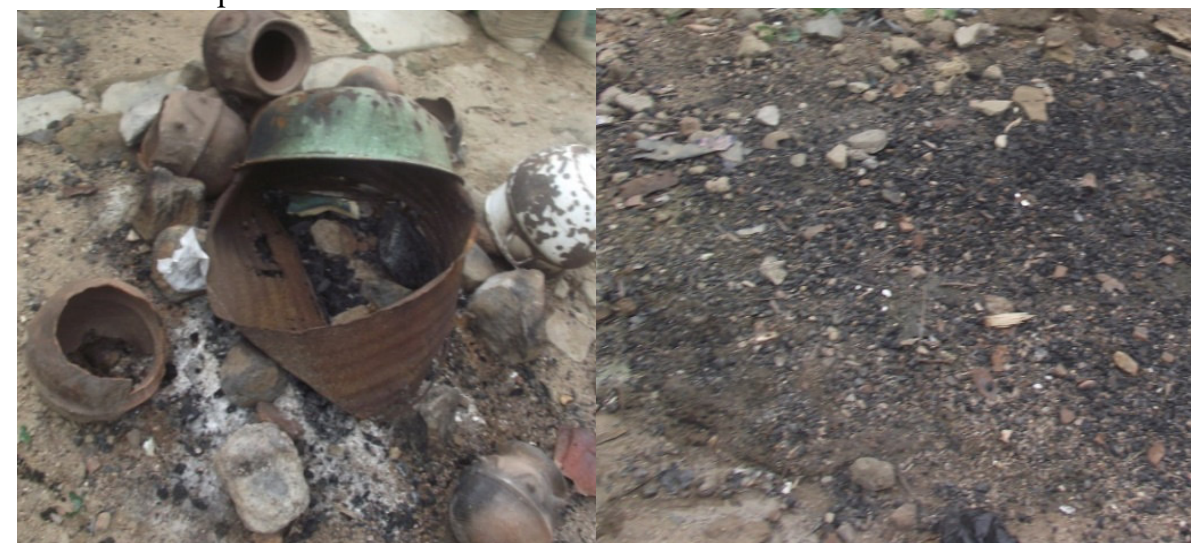

Plate 4: Stones and plastic spatula, Photographed by Clement Adésànyà, 2013.

\section{Relationship between the Art of Pottery and Yorùbá Philosophy (Contextual Significance)}

Art and society in Africa often go in line with the philosophy of the people within the society. This is because art, culture and the society are interrelated. Art generally as a visual form passes information, idea and knowledge to the viewers. Art has been used in time past as tools for socio-control and orderliness among different peoples. 
Some of the vessels (ritual pots) used by the traditional devotees for spirituality have the tendencies to avert evils after all necessary rites might have been made. One of the Yorùbá deities that use pot, Obàtálá, the god of arch divinity of Yorùbá land for instance is said to have the ability to make barren women to be productive, avenge wrongdoing and cure the deformities. Obàtálá is said to be the source of purity, wisdom, creativity, peacefulness and compassion, and that is why the devotees wear white cloth as a means of identification. Òsun goddess also uses pot for its rituals. The ritual pots have the ability to bring things to orderliness when some necessary rites are done. The Africans especially, the Yorùbá people believe that these deities prevent calamity when they are appeased to, offered sacrifices and are supplicated especially in times of distress, illness and misfortune, (Awolalu 1979).

Art of pottery is significant and related to African philosophy because of its functionality. African people believe in functionality of an object rather than its aesthetic values. The pots that are being used for household purposes are significant according to my informant in the sense that, they are desirable and can retain heat as well as cooling effect. İsaasùn and àmù are best example of this. While ìsaasùn keeps food and stew warm for preservation; àmù keeps water cool and cold. Apart from this, using indigenous clay pot helps to retain nutrients of food cooked in it, and also gives good flavor to the food. All this is possible because its process of cooking is slow and that cooking in the pot retains the temperature for a longer period of time. This is what makes it difficult for the food cooked in it to easily spoil. The food cooked in indigenous clay pot is healthier and medicinal than that of foreign vessels. Indigenous people of Africa therefore prefer locally made vessels to foreign articles because they have their peculiar advantages, and as such it is pride for them to use their own products.

Placenta pot (agbébi) on the other hands complements African philosophy and belief that, placenta has capacity to mar the destiny of the newly born baby especially when the evil people evoke it. Placenta is buried immediately after the birth of a child. There are cases where the mother of the newly born baby would be the one to bury this placenta with the pot, indicating that as she buries the plancenta, she would not bury the baby with her own hands. According to adherents of Ọșun, barren women become mothers when they drink from the Ọșun water.

\section{Classification of Forms, Motifs and Functions of Yorùbá Pottery (With Respect to Madam Solá Sódàmọ́lá Abàtì)}

Forms and motifs across the ages in art often determine the function to which the object of art performs. Art in African societies is created to perform a specific function against its aesthetic purpose. Aremu (2002) and Kalilu (2006) classify pottery products according to their forms and functions into nine among which are; conical, spherical or globular, cylindrical, flat and disk-like, rectangular and tabular. Going by this classification, one would perceive that form duly dictates functions to which pots are put. Kalilu further informs that it is within these nine overarching forms that other variations exist. Ibigbami (1981) classifies pottery into three main categories: big pots, small pots and; ritual and ceremonial pots. All these categories are narrowed down to the specific functions they perform. Willett (1976) suggests that form rather than function should be used as the basis for the classification of traditional Yorùbá pottery vessels. It is important to mention that Yorùbá pots are named after the specific functions they perform e.g "ikòkò omi" which means water pot, "ikòkò àgbo" i.e. concoction pot and "ikòkò aró" meaning, dyeing pot. What each of these pots is used for is named after its name.

For the purpose of this study however, the available pottery products of Madam Solá would be classified into secular and sacred purposes and, they shall be discussed accordingly. Secular here simply indicates household and general uses that do not contain any spirituality. Sacred on the other hand is affixed or set apart for the purpose of religion or spirituality. The products that fall under these two categories shall be scrutinized. It should be noted that some pottery products can also serve both secular and sacred purposes depending on the purpose attached to it by the users. Madam Sọlá claims that, she makes her art as ordinary vessels without any spiritual invocation but, once these vessels get to the final consumers, they can be used for any purpose as ascertained by Adépégba (1984) that some of the pots that are used for ritual purposes are specifically made as household pots before being adopted as ritual pots. Hence, pottery generally anywhere in Africa tends to serve both secular and sacred purposes depending on the importance attached to it by the individual users.

\subsection{Secular Purpose of Pottery}

As mentioned earlier, secular purpose of pottery encompasses all household utensils to the decorative ones in some cases. Decorations on some pots according to Kalilu and Areo, (2013) are determined by the eventual function and usage. "Ajere" which means colander (Plate 5) is usually covered all over with perforations because of the likely sieving job it would perform. Many times, this "ajere" is used to smoke fish and any other things like cheese and meat. 


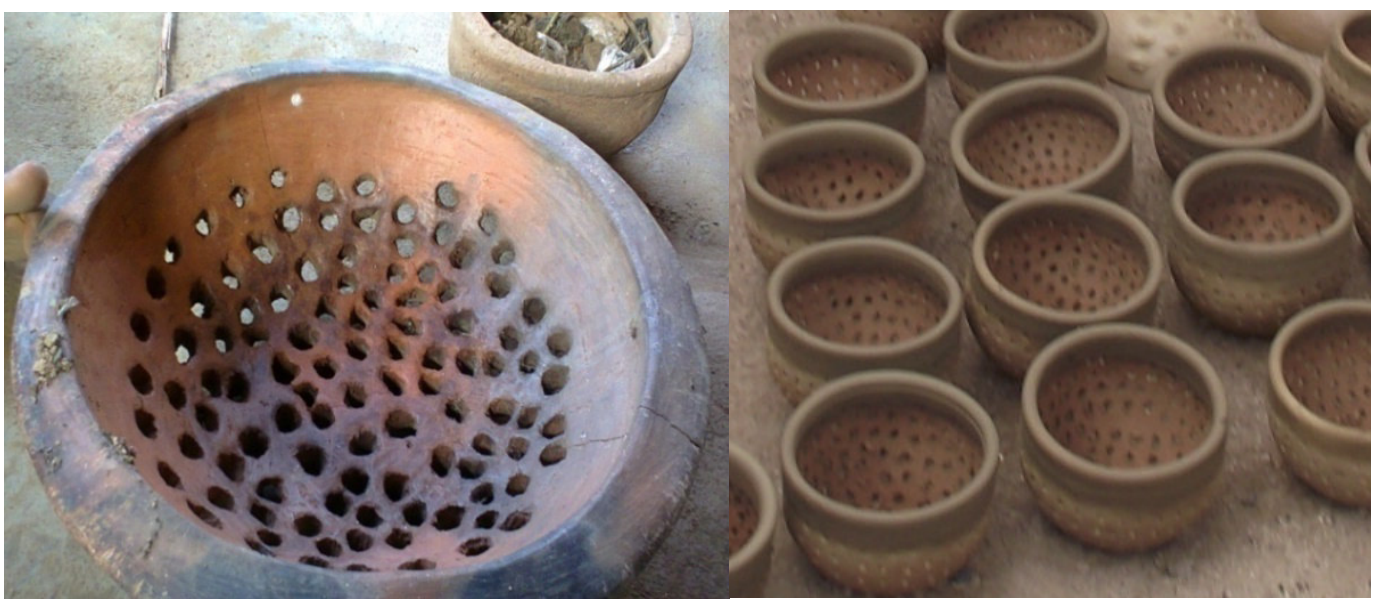

Plate 5: Ajere (Colander), Sọlá Sódàmọ́lá, Abẹòkúta, Photographed by Kệhìndé Adépégba, 2013.

It is also usea to sleve tocust vean alter deing soaked in water in oraer to separate powaer irom tne seed which would be further processed as spices (irú) that give flavour to our soup. The usefulness of pottery vessels in African traditional societies especially in Yorùbá society cannot be over-stressed and, this is because they serve so many domestic purposes. Again, "ikòkò omi" which is called water pot is used for storing water (Plate 6). It is globular in shape. These "ikòkò omi" also known as "àmù" which are large in sizes to contain drinking water for the entire household according to Aremu (2002), are also used for storing food items such as grains, flours, palm wine, and sometimes for dyeing cloth. It should therefore be noted that pottery vessels serve several of purposes in dishes ranging from cooking to eating.

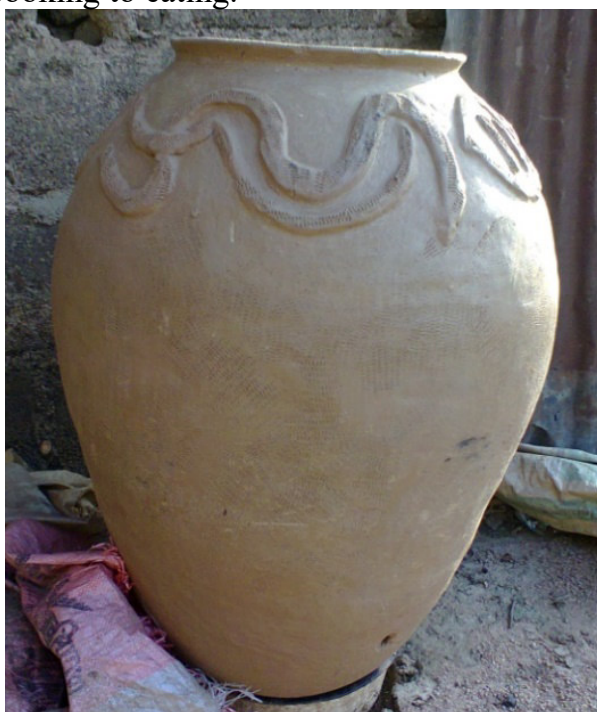

Plate 6: Ìkòkò Omi (Water Pot), Sọlá Sódàmọ́lá, Abẹòkúta, Photographed by Kệhìndé Adépégba, 2013.

The shape of the pot makes it convenient to serve many purposes. Some pots are made in form of oval shape to serve the purpose of cooking though; the functionality of these vessels according to my informant varies from one society to the other even, among the Yorùbá people. This oval shape vessel is called "İkòkò Ìdáná" i.e. cooking pot (Plate 7) 


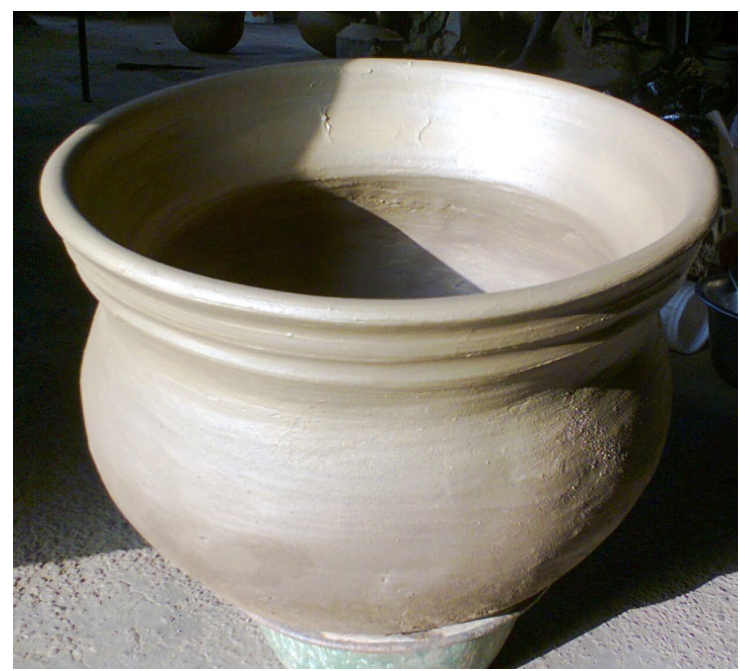

Plate 7: İkòkò İdáná (Cooking Pot), Sọlá

Sódàmọ́lá, Abẹèkúta. Photographed by Clement Adésànyà, 2013.

It is used for cooking foods such as yam, ẹbà, àmàlà, rice etc. Adépégba (1995) also supports the fact that the same pot serves different purposes depending on the society. He further claims that pots mostly serve as vessels but the uses in Nigeria vary considerably according to places and their forms. Although, there are some vessels which could not be used for any other purpose except those ones in which they have been put. Examples of such vessels are, serving plates (àwo ijẹun) (Plate 8), soup pots ìsaasùn (Plate 9), and earthen stove (Àdògán) (Plate 10).

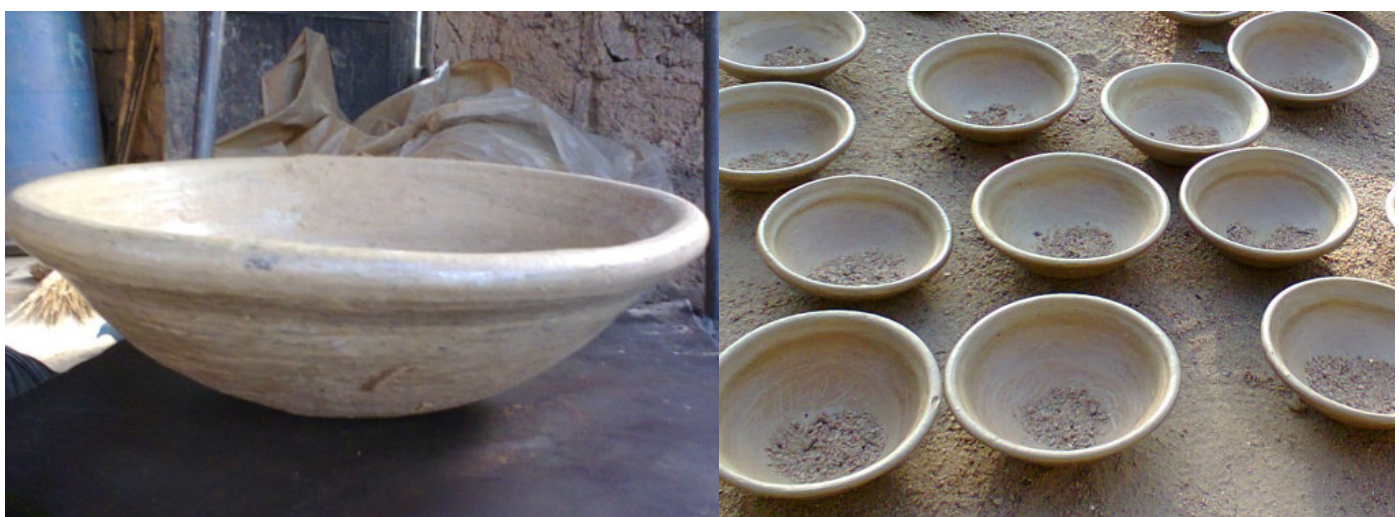

Plate 8: Ȧwo İjẹun (Serving Plates), Sọlá Sódàmọ́lá, Abẹòkúta. Photographed by Isaac Abàtì, 2013.

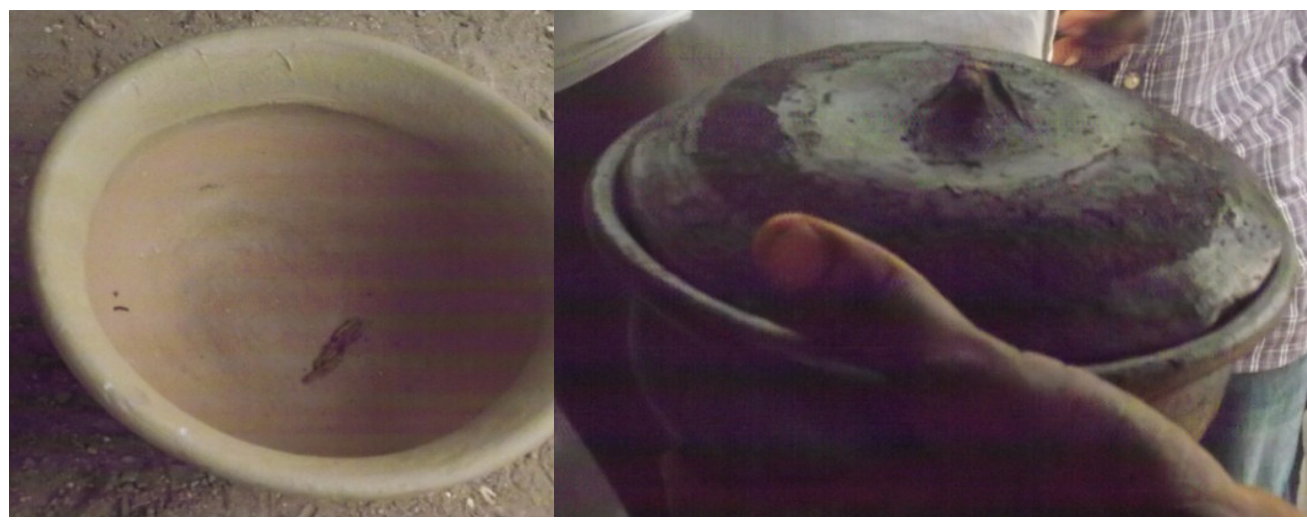

Plate 9: İsaasùn (soup pot), Sọlá Sódàmọ́lá, Abẹò̀úta. Photographed by Isaac Abàtì, 2013. 


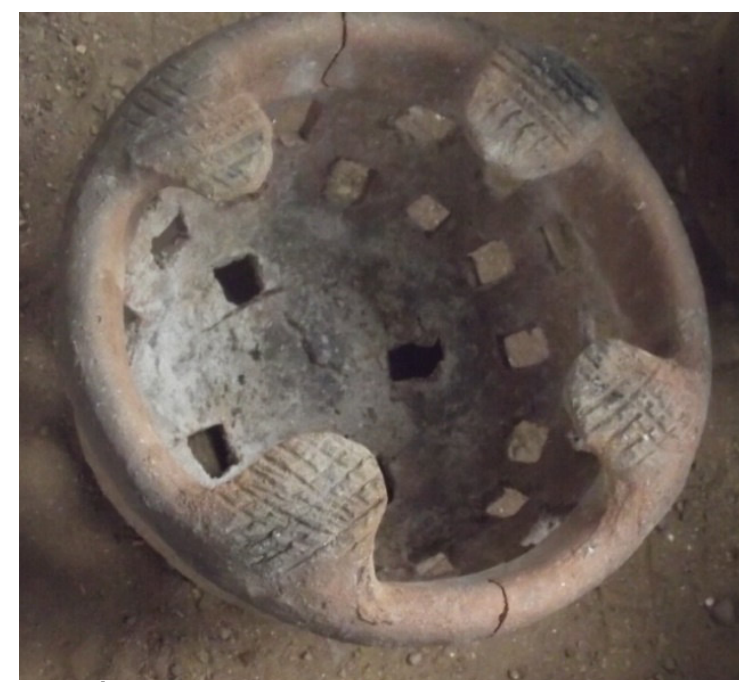

Plate 10: Adògán (Earthen stove), Sọlá Sódàmọ́lá, Abẹoòkúta.

Photographed by Kệhìndé Adépégba, 2013.

All these pots can only be used for the purpose to which they are attached to except for other use like ritual or spiritual purpose (Madam Sọlá). Serving plates are used to serve different foods while, "ìsaasùn" is used for cooking stew and draw soup (i.e. the likes of ewéédú, ilá). "Àdògán” on the other hands, serves the purpose of traditional cooking stove. Other vessels include flower pot (ikòkò Fúláwà) (Plate 11), which serves decorative/aesthetic or otherwise depending on the users. "Fitílà" i.e. traditional lamp is another form of pottery which serves utilitarian purpose of lighting to provide illumination.

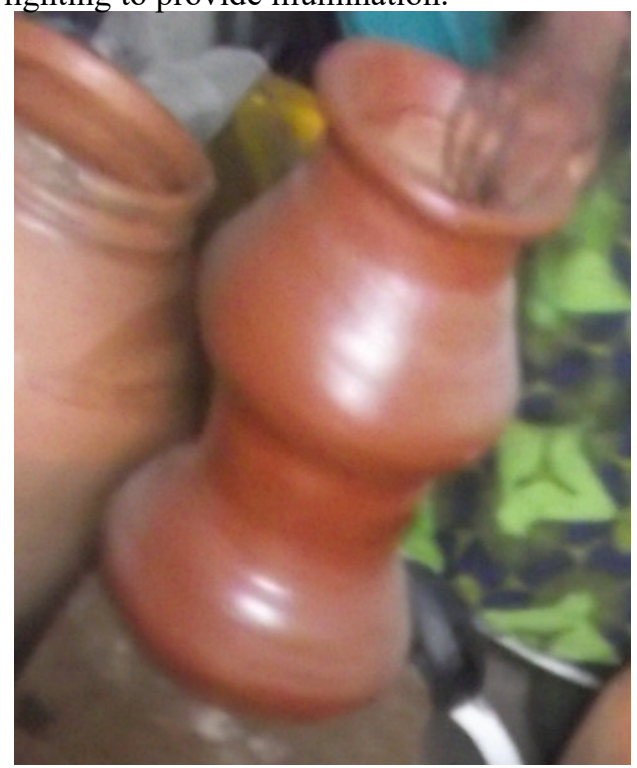

Plate 11: İkòkò Fúláwà” (Flower Pot/Vase), Sọlá Sódàmọ́lá, Abẹòkúta. Photographed by Clement Adesanya, 2013.

\subsection{Sacred Purpose of Pottery}

Pottery across African societies has served sacred purposes depending on the form and motifs incised on the pots. These same pottery vessels have also played vital roles in promoting African religions, cultures and societies. Ritual pots (Plate 12a\&b), for example are produced and meant for religious purpose.

The motifs depicted on the pots will determine the deity for whose devotion is made. The Obàtálá ritual pot (Plate 12a), according to my informant is produced for Obàtálá, so the devotees use the pot for the worship of Ọbàtálá at its rituals. Other devotees that use ritual pot as it is claimed by Madam Sọlá Sódàmọ́lá include Ọ̣ṣun, Olókun, Ògún and Alárá -Igbó devotees. The pot designed for Obàtálá is decorated with cowries' motifs being one of the symbols of Obàtálá. The other pot (plate 12b) is used for different healing purposes. The rituals that are made through these pots bring about healing power and religious experience of a particular people. They constitute religious expression of African people to the supernatural being. 


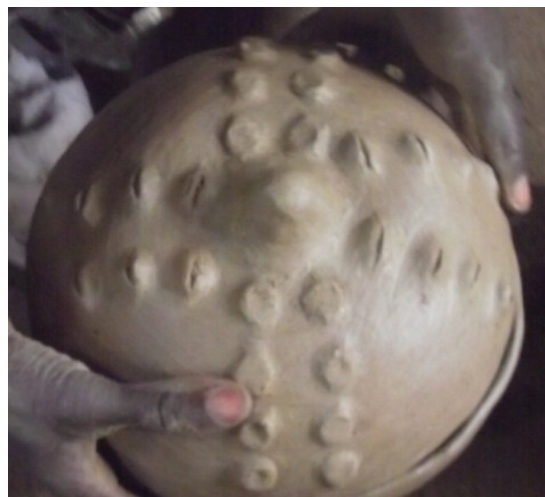

Plate 12a: Obàtálá Ritual Pot, Sọlá Sódàmọ́lá, Abẹòúta.

Photographed by Kẹ́hìndé Adépégba, 2013.

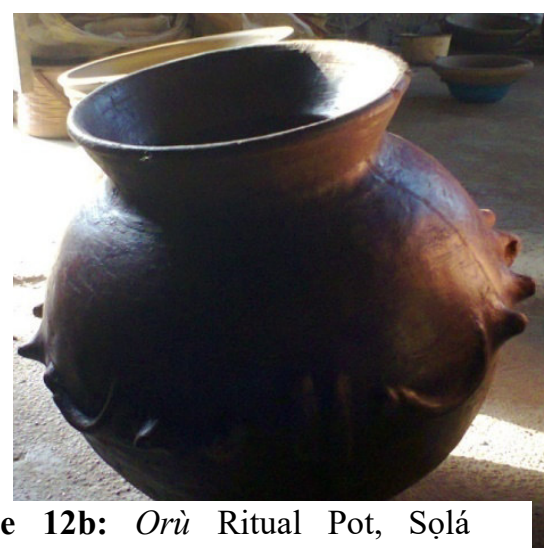

Sódàmólá, Abéòkúta.

Photographed by Kẹ́hìndé Adépégba, 2013.

"Agbébi" (Plate 13), which is called placenta pot is another vessel that serves sacred purpose. It is sacred in the sense that placenta according to the traditional Yorùbá belief is very important as the newly born baby itself. The placenta is handed over to the father of the new baby after delivery to be buried for spiritual purpose. It is usually kept inside "agbébi" pot which must be buried with it. The location where the placenta is buried is also important because, wicked people might use the placenta to invoke misfortune and calamity into the life of the newly born baby. This same placenta pot is also used to carry sacrifices. Again, "ajere" (Plate 5 above) as it has been earlier mentioned serves dual purposes of secular and sacred. The same colander/perforated pot that is used for smoking fish is also used for burning incense according to my informant. Perforated pots are used by some devotees to burn incense to the Supreme Being.

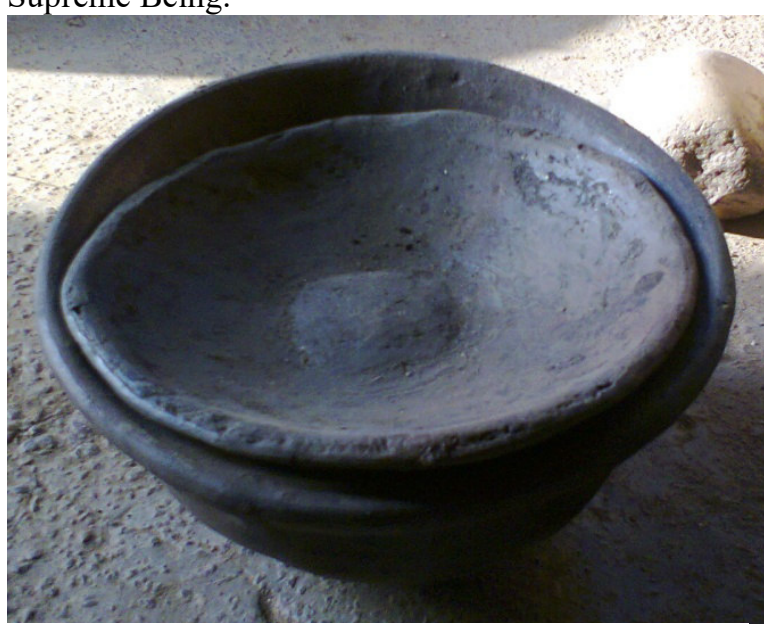

Plate 13: Agbébi (Placenta Pot), Sọlá Sódàmọ́lá, Abẹòkúta. Photographed by Isaac Abàtì, 2013. 


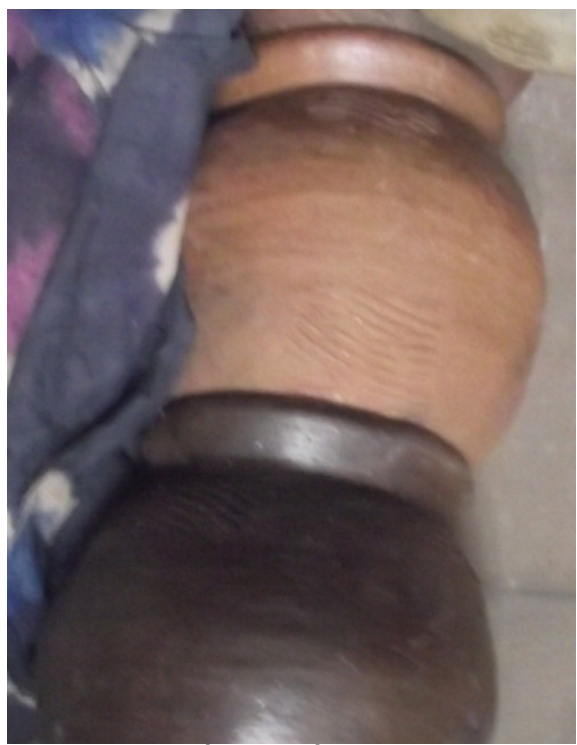

Plate 14: Orù/Ìkòkò Àgbo (Concoction Pot), Sọlá

Sódàmọ́lá, Abẹòkúta.

Photographed by Kệhìndé Adépégba, 2013.

"Orù" (Plate 14), which is also called concoction pot (ikòkò àgbo), is used to cook concoction and herb for human consumption in order to make sick people recover from a particular illness. Mostly, herbs are cooked inside the "orù" to make it more efficacious. Pottery generally in the traditional African society and even in our contemporary world serves tremendous purposes in uplifting our culture. It is imperative therefore that our culture and traditions are taken with all seriousness.

\section{Relevance and Patronage}

The extent to which the art of pottery is relevant in our contemporary society would be determined by the value being placed on it by the users. Its continuity also determines the caliber of people who engage in the art. According to my informant, the younger ones of this age have left the art of pottery for the elderly ones. The question now is that, "what becomes of the tradition after these old people might have passed away to the underworld? It is also good to note that the pot patronage determines the relevance in the society. The people who buy and use the pottery vessels actually place value on them and consequently, it is relevant to them. My informant claims that, people patronize her art especially the Atamara people from Ọsun state. People also come from other places which includes outside this country. The same group of people who value the traditional art of pottery are the ones patronizing it for traditional purpose indicating that, so many people are not interested in the art any longer because they prefer modern vessels to it. However, there are some situations in which traditional pottery vessels cannot be substituted for; the socio-cultural and religious functions that pots serve cannot be equated with any of these foreign materials.

Many people in this contemporary age do not want to use pottery products for household dishes any more except for a few of them who prefer the products after they might have been glazed. The question of continuity or discontinuity is however determined by the relevance of the pottery tradition to its people and the value they place on it. There is no doubt about the positive patronage especially the traditional pots according to my informant but, the question still remains that do people use them for the purpose of preserving and promoting our culture? However, my informant claims that some indigenous people prefer water pot for its cooling ability and also, soup pot (ìsaasùn) because of its warming value.

According to Sọlá Sódàmọ́lá, the marketing of pottery vessels still runs fast today in its cultural environment asides its preservative and medicinal abilities. Many elites have resulted to the use of soup pot and water pot because of healing powers that they believe reside in pottery vessels though, this has not been scientifically proven or invalidated. Ùmórù-Ọkẹ (2011) also stresses that the marketing is encouraging when she reveals that, "in the past, the finished products were carried to near-by villages and markets for sale but, nowadays, potters remain in their pottery shed and people come from both far and near to buy them". It should be noted therefore that, it is interesting that this art has future. The only aspect that is much embraced is the household vessels. The cultural aspect is running into extinction gradually.

Nobody wants to eat or even drink concoction from the local pot anymore. Burying placenta with the "agbébi" is not common again because in most cases, these placentas are being flushed into the water closet toilet by the midwives. The parent of the newly born may not know what happens to the placenta of their baby, 
and may not even see it before it will be disposed. This was not so in an ideal traditional African society in the past. However, the traditional motifs incorporated in to the vessels by the potters still make the art of pottery relevant in its cultural context. This will eventually inform the society about our heritage and rich culture thereby embracing it for continuity and preservation.

\section{Conclusion}

The paper has dwelled on the art of pottery of Madam Sọlá Sódàmọlá Abàtì and has justified the fact that pottery making will still continue to be relevant in our society as it were in the time immemorial. Pottery is an aspect of our material culture which keeps the fire of Yorùbá culture and tradition burning provided, both the young and old embrace it. The paper has also discussed the relativity of pottery to Yorùbá philosophy as well as its relevance in the modern times. It is therefore noted that the young people's orientation and attitudes towards the local products are not encouraging enough to sustain the tradition to some extent. This is because so many of them prefer white collar job to pot making and most users prefer imported products of plastic and wares enamel to pottery vessels. Therefore, it is important to orientate our people to encourage the patronage of pottery products in contemporary time so as to make it more relevant. The young ones should also be encouraged to embrace the art whether by apprenticeship or formal training (school setting learning). The socio-cultural and household functions of this traditional Yorùbá pottery cannot be likened or equated with any foreign articles/products.

\section{References}

Adépégba, C. O. (1984): The Essence and Art of Yorùbá Sanctuary Pottery, Ibadan: Orita, Journal of Religious Studies, Vol. 2, and No.1.

(1995): Nigerian Art: Its Tradition Tendencies: JODAD, Ibadan

Ahuwan, (2003): Contemporary Ceramics in Nigeria: 1952 - 2002: Achievements \& Pitfall, Ashakwu Journal of Ceramics, Zaria: Dasma Press, Vol 1 (1)

Aremu, P.S.O. (2002): Yorùbá Pottery: Cultural Manifestation: Journal of Arts and Ideas, Vol. 4, ISBN $1118-$ 7228, March, 2002: Pp $42-50$.

Awolalu, J. O. (1979): Yorùbá Beliefs and Sacrificial Rites: Longman Group Limited London.

Fowowe, M. (1984): Yorùbá Traditional Art: Symbolism and Interpretation: Marilyn Zurmuehlen Working Papers in Art Education, Vol. 3, Issue 1, Article 12. Retrieved (June 13th, 2013) from $\mathrm{http} /$ ir.uiowa.edu/mziop/vol3/iss1/12.

Gillion, W. (1984): A Short History of African Art. London: Pengium Books

Ibigbami, R.I. (1975): Aspects of Yorùbá Traditional Pottery Techniques, Ile-Ife: Journal of African Studies, University of Ife.

Igwillo, B. (1983): Traditional Pottery in Nigeria, Lagos: Nigerian Magazine, No 147, Pp 35 - 46

Inside Watch Africa (2012): Abẹ́òkúta: A City founded under the Rock: Retrieved (June 14th, 2013) from http://www.insidewatchafrica.com

Kalilu, R.O.M. (2006): Ceramics: Art and Technology in the 21st Century Southwestern Nigeria: PEMILTER, Lagos.

Kalilu, R.O.M. and Areo, M.O., (2013): Cross-Current and Transmigration of Motifs of Yorùbá Art: An International Journal of Arts and Humanities, Balur Dar, Ethiopia, Vol. 2 (2) No 6, Pp 108 - 129

Ojo, J. R. O. (1986): Art, A New History of Nigeria for Colleges, Peoples, State and Cultures Before 1800. Book One, In T. Falola \& A. Adeniran (eds.), Algeria: John West Printing Division

Okunna, E. (2004): Traditional Pottery Practice in Contemporary Nigeria. In T.L. Akinbogun et.al (eds), Akure: Nigerian Crafts and Techniques, Nigerian Craft Forum, Development of Industrial Design., Federal University of Technology, Akure, Nigeria

Shaw, T. (1978): Nigeria: Its Archaeology and Early History. London: Thames and Hudson

Úmórù-Òkẹ, N., (2011): A Study of Pottery Practices in Some Selected Centers in Yorùbá land, A Master of Philosophy Thesis (Unpublished) submitted to the Department of Fine and Applied Arts, Obafemi Awolowo University, Ile-Ife, Nigeria

N. (2016): A Study of Indigenous Potters in Yorùbá Culture Area of Nigeria, A Doctor of Philosophy Thesis (Unpublished) submitted to the Department of Fine and Applied Arts, Obafemi Awolowo University, Ile-Ife, Nigeria

Vanguard Media Limited (2011): Art of Traditional Pottery in Nigeria. Retrieved (June 15th, 2013) from http://www/vangardngr.com

Willet, F. (1996): Pottery Classification in African Archaeology: West African Archaeology Newsletter 
Informants

Personal Communication (June, 2013) with Madam Sọlá Sódàmọ́lá Abàtì, 40 years, Traditional Yorùbá, Potter, Abẹèkúta, Ogun State.

Personal Communication (June, 2013) with Jegede Lanre, 38 years, An Attendant in Alake of Ègbá Palace, Abẹòkúta, Ogun State. 